\author{
ŁUKASZ GĄSIOR, ZBIGNIEW POLAŃSKI \\ Instytut Zoologii i Nauk Biomedycznych \\ Uniwersytet Jagielloński $w$ Krakowie \\ Gronostajowa 9, Kraków 30-387 \\ email: lukasz.gasior@doctoral.uj.edu.pl
}

\title{
MOŻLIWOŚCI PRZYWRACANIA I UTRZYMANIA JAKOŚCI MITOCHONDRIÓW W OOCYTACH SSAKÓW
}

\section{WSTEP}

$\mathrm{Na}$ podstawie dotychczasowych obserwacji organizmów modelowych wiadomo, że większość mutacji somatycznych gromadzi się w komórkach wprost proporcjonalnie do wieku (MosKALEV i współaut. 2013). W przypadku wystapienia mutacji w komórkach rozrodczych, moga być one przekazywane $z$ pokolenia na pokolenie, a schemat ten znajduje także swoje odzwierciedlenie w ludzkim organizmie (ACUNA-HIDALGO i współaut. 2016). Stwierdzono, że wraz $z$ wiekiem $\mathrm{u}$ kobiet rośnie poziom stresu oksydacyjnego w oocytach, co skutkuje dysfunkcja mitochondriów i koreluje ze wzrostem liczby uszkodzeń oraz mutacji w mitochondrialnym DNA. Z biegiem czasu obserwuje się również zmniejszenie liczby kopii mitochondrialnego DNA (mtDNA) (BABAYEV i SELI 2015).

Mitochondrialny DNA jest głównym celem dla mutacji somatycznych zwiazanych $z$ procesem starzenia. Za główne przyczyny uszkodzeń mtDNA uznaje się utleniające mikrośrodowisko mitochondriów i brak ochrony zapewnianej przez histony (LINNANE i współaut. 1989). Dodatkowo, genom mitochondrialny nie posiada tak wydajnych systemów naprawczych jak genom jacdrowy, co zwiększa jego podatność na stopniowe gromadzenie się w nim mutacji (LARSsoN 2010). Uszkodzenia mitochondriów, głównych centrów energetycznych komórki, moga prowadzić do dysfunkcji łańcucha oddechowego, stanowiąc przyczynę wielu ludzkich chorób.
Choroby mitochondrialne obejmuja zaburzenia neurologiczne, miopatie, cukrzycę i wiele endokrynopatii (ZEVIANI i DI DONATO 2004). Badania na mysim modelu potwierdziły, że zaburzenia w mechanizmach naprawy DNA przyśpieszaja procesy starzenia oraz leżą u podstaw ludzkich zespołów chorobowych, takich jak zespół Wernera, zespół Blooma, skóra pergaminowa, trichotiodystrofia, zespół Cockayne’a i zespół Seckela (HoEIJMAKERS 2009, MURGA i współaut. 2010, GREGG i współaut. 2013). Choroby mitochondrialne, takie jak zespół Kearnsa-Sayre i zespół Pearsona, sa wynikiem rearanżacji mtDNA na dużą skalę, natomiast zespół MELAS (encefalopatia mitochondrialna), dziedziczna neuropatia nerwu wzrokowego Lebera (LHON) i zespół MERRF są powodowane mutacjami punktowymi (ZEVIANI i DI DONATO 2004). W przypadku niedoboru koenzymu Q10 i zespołu Bartha mutacji ulegaja geny kodujace enzymy fosforylacji oksydacyjnej kodowane w mtDNA (ZEVIANI i DI DONATO 2004). Dotychczasowe badania populacyjne ujawniły, że przynajmniej jedna osoba na dwieście niesie mutacje mitochondrialne, które potencjalnie zdolne sa powodować poważne choroby (ELLIOTT i współaut. 2008). Mimo tego rzeczywiste choroby mitochondrialne występuja w populacji ludzkiej w znacznie niższej proporcji $(1: 5000)$ i jest to spowodowanie efektem maskowania mutacji przez nienaruszone mitochondria (SCHON i współaut. 2012).

Wraz $z$ wiekiem liczba mutacji gwałtownie wzrasta, zarówno w komórkach linii 
płciowej, jak i w komórkach somatycznych (KHRAPKO i TURNBULL 2014). Wiadomo, że mutacje mitochondrialne negatywnie wpływają na płodność i moga przyczyniać się do utraty rezerwy jajnikowej i przedwczesnej menopauzy (WANG i Sun 2007). Przypuszcza się, że linia komórek płciowych ma mechanizmy pozwalajace na ograniczenie liczby mutacji $\mathrm{w}$ obrębie genomu mitochondrialnego przekazywanego potomstwu, które jednak nie są w stanie wyeliminować wszystkich nieprawidłowości (MARLOW 2017). Dla polepszenia płodności człowieka poszukuje się sposobów wspomagania pracy mitochondriów lub usuwania zmutowanych kopii mtDNA $z$ linii płciowej. Badania na tym polu sa jednak wciąż bardzo ograniczone ze względu na zasadnicze luki w znajomości procesów regulujących aktywność, replikację czy dziedziczenie mitochondrialnego DNA. Dlatego możliwości działania w przypadku występowania poważnych nieprawidłowości w genomie mitochondrialnym ograniczaja sie głównie do suplementacji antyoksydantami i inwazyjnych technik transferu genomu pomiędzy komórkami.

\section{DIETA A STAN MITOCHONDRIÓW}

Oocyty przetrzymywane poza organizmem narażone sa na działanie środowiska hiperoksydacyjnego, czego konsekwencją jest powstawanie reaktywnych form tlenu (RFT) (Combelles i współaut. 2009). Jest to zjawisko niekorzystne, zwłaszcza $z$ punktu widzenia technik wspomaganego rozrodu (ART) obejmujacych manipulacje oocytami czy też hodowle oocytów i zarodków in vitro. Mimo wszystko, pewien zakres poziomu RFT generowanych w takich warunkach jest tolerowany w krótkiej perspektywie czasowej i komórka radzi sobie utrzymujac stan homeostazy RFT dzięki aktywności enzymów antyoksydacyjnych, takich jak: dysmutaza ponadtlenkowa, katalaza czy peroksydaza glutationowa, oraz produkcji cząsteczek antyoksydacyjnych jak np. zredukowany glutation (IKEDA i współaut. 2014). Wiadomo jednak, że przekroczenie krytycznego poziomu RFT w płynie pęcherzykowym wywołuje zaburzenia w rozwoju przyszłego zarodka (LIM i LUDERER 2011). Niedobór w diecie antyoksydantów, takich jak witamina E, prowadzi do wzrostu poziomu RFT w jajniku, degeneracji pęcherzyków jajnikowych, hipertrofii komórek ziarnistych i spadku masy macicy u myszy (RUDER i współaut. 2009). Podawanie antyoksydantów dorosłym samicom myszy może odwlec w czasie wystapienie zaburzeń mitochondrialnych w oocytach oraz zwiększać liczbę owulowanych oocytów (TARÍN i współaut. 2002). Ponadto, antyoksydanty stymu- luja uwalnianie gonadotropin $z$ przysadki, co ma dodatkowy pozytywny wpływ na płodność (RUDER i współaut. 2009). Niestety korzystne efekty działania antyoksydantów obserwowano zwykle dopiero po zastosowaniu dużych dawek lub po długim czasie (TARíN i współaut. 2002, RUDER i współaut. 2009). Stwarza to ryzyko skutków ubocznych przy próbach stosowania takich terapii u ludzi. Dla przykładu, duże dawki witaminy A działają embriotoksycznie i teratogennie. Z kolei wysokie dawki innego antyoksydantu, jakim jest witamina $\mathrm{C}$, moga hamować jajnikowa steroidogenezę, zmniejszać płodność, podnosić prawdopodobieństwo utraty ciąży, a także uszkadzać nerki (TARIN i współaut. 1998). Ponadto, utrzymanie odpowiedniego poziomu RFT jest konieczne dla proliferacji komórek zrębowych pęcherzyków jajnikowych pełniących funkcje steroidogenne (DULEBA i współaut. 2004). Co więcej, wiele badań wskazuje, że odpowiednia ilość reaktywnych form tlenu jest również niezbędna do wznowienia mejozy w oocytach, a wejście komórek w stadium metafazy I (MI) może być hamowane przez podawanie antyoksydantów (RUDER i współaut. 2009). Wiadomo, że pewien poziom reaktywnych form tlenu jest też konieczny do prawidłowego funkcjonowania całego organizmu. Dlatego jako przyczynę wzrostu liczby uszkodzeń komórkowych będacych wynikiem działania RFT wskazuje się raczej postępujaca $z$ wiekiem utratę zdolności do utrzymania homeostazy RFT, co jest konsekwencja zwiazanego $z$ wiekiem spadku ekspresji genów białek antyoksydacyjnych (LIM i LUDERER 2011). Wydaje się więc, że jedna $z$ głównych ról $w$ utrzymaniu jakości oocytów odgrywa ochrona stanu mitochondriów w długiej perspektywie czasowej.

Dojrzewanie mejotyczne jest etapem rozwoju oocytów obejmujacym pierwszy podział mejotyczny, definiowanym jako wznowienie podziału mejotycznego przez oocyty zablokowane w profazie I, do osiagnięcia stadium metafazy II. Procesowi temu towarzyszy rozpad otoczki jadrowej, przegrupowanie cytoszkieletu i formowanie się wrzeciona podziałowego, zachodzi również szereg procesów przygotowujących oocyt do właściwej odpowiedzi na penetracje przez plemnik i podtrzymania wczesnych stadiów rozwoju (GREENSTEIN 2005). Niedługo przed podjęciem dojrzewania mejotycznego oocyty staja się transkrypcyjnie nieaktywne i w tym stanie ATP jest potrzebny tylko do utrzymania podstawowych funkcji życiowych komórki i formowania się wrzeciona podziałowego (BAIRD i współaut. 2005). Zgodnie $z$ tym modelem, myszy $z$ insulinoopornością, cukrzyca i otyłością, a więc chorobami metabolicznymi zaburzajacymi status energetyczny komórki, 
cechują się wzrostem liczby oocytów o nieprawidłowo uformowanym wrzecionie podziałowym, wyższym poziomem aneuploidii, $z$ jednoczesnym wzrostem liczby defektywnych mitochondriów (WANG i współaut. 2009). Cukrzyca i hiperglikemia występująca przed rozpoczęciem ciąży i/lub w okresie ciąży prowadza do obniżenia płodności kobiet (AMARAL i współaut. 2008). Ponadto, pacjentki $z$ insulinoopornościa i hiperinsulinemia sa obarczone wyższym ryzykiem niepowodzeń w implantacji zarodka i utraty ciąży $z$ powodu niskich kompetencji rozwojowych oocytów (Ou i współaut. 2012). Badania nad efektywnościa transferu zarodków pochodzących bądź z oocytów autologicznych lub od dawczyń wykazały, że otyłość drastycznie obniża możliwości zajścia w ciażę (LUKE i współaut. 2011). W badaniach tych przeanalizowano efekty ponad 45.000 transplantacji zarodka w technikach wspomaganego rozrodu i wykazano, że przeszczepienie zarodka uzyskanego $z$ oocytu otyłej kobiety (przeszczep autologiczny) nie poprawia szansy na uzyskanie ciązy, natomiast przeszczep zarodka pochodzacego $z$ oocytu szczupłej dawczyni (przeszczep allogeniczny) podnosi szansę na zajście w ciążę (LUKE i współaut. 2011). Zjawisko to może być związane $z$ jakościa mitochondriów. Badania na modelu mysim wskazuja, że oocyty samic, u których indukowano sztucznie otyłość mają zaburzenia zarówno w ultrastrukturze mitochondriów, jak i ich rozmieszczeniu w cytoplazmie. Co ciekawe, oocyty takich myszy posiadaja większa liczbę kopii mtDNA, $z$ jednocześnie dużo niższym poziomem ATP i ponad dwukrotnie wyższym poziomem RFT (WANG i współaut. 2009). Dlatego dieta matki może odgrywać znaczaca rolę w profilaktyce utrzymania płodności i zapobiegać utracie jakości mitochondriów i samych oocytów w starzejacych się jajnikach. Dla przykładu, dieta bogata $\mathrm{w}$ tłuszcz przyspiesza utrate peccherzyków jajnikowych, prowadzac do przedwczesnej niewydolności jajników (POF) (WANG i współaut. 2014). Ponadto, przy zastosowaniu takiej diety obserwuje się zaburzenia w liczbie i wielkości grzebieni mitochondrialnych oraz wzrost poziomu aneuploidii (LuzzO i współaut. 2012). W przeciwny sposób działa obniżenie kaloryczności pożywienia. Wiadomo, że redukcja kaloryczności o $40 \%$ łagodzi wiele powikłań zdrowotnych związanych $z$ wiekiem (SELESNIEMI i współaut. 2011). Bardzo ciekawe wyniki dotyczace mechanizmu działania restrykcji kalorycznych przyniosły badania skoncentrowane na PGC-1a (ang. proliferator-activated receptor coactivator1a), który zaangażowany jest w biogenezę mitochondriów, metabolizm glukozy/kwasów tłuszczowych i proces fosforylacji oksydacyj- nej (TATONE i współaut. 2015). Uważa się, że za efekty restrykcji kalorycznych może odpowiadać m. in. PGC-1a (LETTIERI BARBATO i współaut. 2012). SELESNIEMI I WSPÓEAUT. (2011) stwierdzili, że utrata genu kodującego PGC-1a zapobiega aneuploidii oocytów i zaburzeniom budowy wrzeciona podziałowego u starzejących się myszy, w podobny sposób jak restrykcje kaloryczne. Mysz poddana restrykcjom kalorycznym nie wykazuje zwiąanego $z$ wiekiem wzrostu aneuploidii, nieprawidłowości w budowie wrzeciona podziałowego czy też nieprawidłowości w konfiguracji chromosomów płytki metafazowej w oocytach. Brak jest także zaburzeń w ułożeniu mitochondriów i produkcji ATP, a gryzonie poddane restrykcjom kalorycznym utrzymują płodność o wiele dłużej (SELESNIEMI i współaut. 2011).

\section{MITOFAGIA}

Innym mechanizmem łączaccym dietę i jakość mitochondriów może być proces autofagii mitochondriów zwany mitofagia. Proces ten poprzedza asymetryczny podział mitochondriów na mitochondria o większych i mniejszych kompetencjach energetycznych. Te ostatnie ulegaja ubikwitynacji i degradacji w procesie mitofagii zachodzacej w autofagolizosomach (WALLACE i CHALKIA 2013). Stwierdzono, że kinaza mTOR, jeden $z$ kluczowych czujników dostępności substancji odżywczych w organizmach wyższych, jest negatywnym regulatorem mitofagii (GILKERsoN i współaut. 2012). Co więcej, zahamowanie szlaków regulowanych przez analogiczne białko u robaków, muszek owocowych i drożdży skutkuje wydłużeniem okresu życia. U ssaków kinaza mTOR coraz częściej postrzegana jest jako centralny regulator homeostazy energetycznej i metabolizmu komórkowego, który odpowiada za wiele korzyści wynikających $z$ opisanych powyżej restrykcji kalorycznych (MiNOR i współaut. 2010). Obecnie próbuje się uzyskiwać zahamowanie jej aktywności bez potrzeby głodzenia organizmu. Jedna $z$ substancji stosowanych $\mathrm{w}$ tym celu jest rapamycyna, która poprzez blokowanie kinazy mTOR wykazuje działanie antynowotworowe i immunosupresyjne (Minor i współaut. 2010). Jednocześnie doświadczenia pokazuja, że stosowanie rapamycyny może znaczacco wydłużyć życie myszy (HARRISON i współaut. 2009). Badania na modelu świńskim wskazuja, że rapamycyna przywraca prawidłowa strukturę wrzeciona podziałowego w oocytach starzejacych się $\mathrm{w}$ hodowlach in vitro oraz ogranicza nieprawidłowe rozejście się chromosomów w anafazie podziału mejotycznego. Zaobserwowano również znaczacy spadek poziomu 
RFT i fragmentacji DNA w takich oocytach (LEE i współaut. 2014). W przypadku modelu szczurzego rapamycyna zwiększała rezerwę jajnikowa i podnosiła ekspresję SIRT1 i SIRT6, czyli tzw. sirtuin, które są zaangażowane w procesy odpowiedzi komórki na stres i podnoszą możliwości jej przetrwania w niekorzystnych warunkach (ZHANG i współaut. 2013). Potencjalnie więc, farmakologiczne wpływanie na aktywność mTOR mogłoby być wykorzystywane do niwelowania stanu heteroplazmii w komórkach i poprawiać stan mitochondriów (DAI i współaut. 2014). Badania nad wpływem rapamycyny na stan mitochondrialnego genomu sa jednak wcią̇ nieliczne, a niektóre sugerują, że mitofagia wywoływana hamowaniem aktywności mTOR nie działa selektywnie, a więc nie prowadzi do spadku liczby zmutowanego mtDNA w komórkach (DIOT i współaut. 2016). Dodatkowa komplikację przyniosły najnowsze badania wykonane na modelu mysim wskazujace, że oocyty moga być niezdolne do mitofagii w sposób naturalny (BOUDOURES i współaut. 2017). Wciąż więc nie wiadomo, czy rapamycyna jest $w$ stanie zaindukować proces mitofagii, który mógłby wpłynać na liczbę zmutowanego mtDNA w oocytach.

\section{SIRTUINY I STACS}

Sirtuiny funkcjonują jako zależne od $\mathrm{NAD}+$ deacetylazy histonów (HDACs), które oprócz usuwania grup acetylowych wchodza $\mathrm{w}$ interakcje $\mathrm{z}$ wieloma białkami niehistonowymi, włacczajacc w to enzymy metaboliczne. Dzięki reagowaniu na wewnątrzkomórkowy status NAD+/NADH sirtuiny odgrywają ważna rolę w utrzymaniu energetycznego statusu komórki (MOUCHIROUD i współaut. 2013). Białko SIRT1 może kontrolować ekspresję białek naprawczych i antyoksydacyjnych dzięki oddziaływaniu $z$ czynnikami transkrypcyjnymi, np. FoxO (ang. forkhead box O), który zaangażowany jest $\mathrm{w}$ regulacje ekspresji wielu genów odpowiedzialnych za odpowiedź komórki na stres (MOUCHIROUD i współaut. 2013).

W aktywację sirtuin zaangażowane sa szlaki sygnalizacyjne zwiazane $z$ receptorem dla insulinopodobnego czynnika wzrostu (IGF-1R), który stanowi prawdopodobnie kolejny, obok PGC-1a i mTOR, „czujnik” dostępności pożywienia (KENYON 2010). Wpływa on nie tylko na długość życia i naprawy DNA, ale także na aktywność mitochondriów i większą odporność komórek na stres oksydacyjny (LI i współaut. 2014, MURSHID i współaut. 2013). Jako białka $z$ grupy sirtuin zaangażowanych bezpośrednio w utrzymanie jakości oocytów można wymienić białko
SIRT1, które bierze udział w regulacji mejozy, redukcji poziomu RFT, follikulogenezie, proliferacji komórek ziarnistych i regulacji konfiguracji chromatyny oocytu (TATONE i współaut. 2015). Z kolei inna $z$ sirtuin, SIRT2, prawdopodobnie odpowiada za prawidłowe podłaczenie mikrotubul do kinetochorów. Spadek ekspresji genu Sirt2 był obserwowany w oocytach starszych samic myszy, co zostało skorelowane ze wzrostem aneuploidii (ZHANG i współaut. 2014). Wiadomo również, że inne białko $z$ tej rodziny, SIRT3, wspomaga rozwój przedimplantacyjnych embrionów w warunkach stresu oksydacyjnego (KAWAMURA i współaut. 2010). Dla ominięcia prowadzenia uciążliwej diety próbuje się stosować substancje dajace efekt podobny do samych restrykcji kalorycznych, czyli tzw. STACs (ang. SIRT1 activating compounds), i w ten sposób zwiększać ekspresję sirtuin. Jednym $z$ najefektywniejszych STAC podnoszacych ekspresję sirtuin jest naturalnie występujacy w czerwonym winie resweratrol. Zwiazek ten udowodnił swoja skuteczność w przywracaniu i utrzymywaniu kompetencji rozwojowych oocytów ssaków (SATO i współaut. 2014, TAKEO i współaut. 2014). Wykazano, że resweratrol, oprócz zwiększania ekspresji SIRT1, zwiększa liczbę kopii mtDNA w swińskich oocytach (SATO i wspólaut. 2014). Zwiazek ten zabezpiecza również jajniki myszy przed starzeniem się (TATONE i współaut. 2015), a także podnosi potencjał błony mitochondrialnej i zawartość ATP w oocytach krowich, zwiększając odsetek uzyskiwanych ciąż (TAKEO i współaut. 2014).

Kolejnym czynnikiem, który można zaliczyć do STAC jest melatonina, która jednocześnie jest silnym antyoksydantem naturalnie występującym w organizmie i kontrolujacym zegar dobowy. Melatonina zabezpiecza komórki przed działaniem stresu oksydacyjnego, zwiększa ekspresję sirtuin, białek antyapoptotycznych oraz podnosi poziom autofagii poprzez szlaki zwiąane $z$ kinaza mTOR (JENWITHEESUK i współaut. 2014). Wiadomo, że melatonina jest naturalnie produkowana przez otaczajace oocyt komórki ziarniste, a jej dodanie do medium hodowlanego podnosi aktywność metaboliczna tych komórek i obniża produkcje RFT w mitochondriach oocytu (EL-RAEY i współaut. 2011). Niektóre badania dowodza, że suplementacja melatonina może podnieść jakość oocytów i zapewnić ochronę przed indukowanym stresem oksydacyjnym (TAMURA i współaut. 2008), a wzbogacanie medium hodowlanego o ten hormon zwiększa odsetek oocytów zdolnych do podjęcia dojrzewania mejotycznego (BAHADORI i współaut. 2013). LORD i współaut. (2013) wykazali ponadto, że melatonina jest w stanie spowolnić proces starzenia posto- 
wulacyjnego oocytów, wydłużając przedział czasowy, w którym oocyty moga zostać prawidłowo zapłodnione.

\section{SUPLEMENTACJA ZWIAZKAMI WPEYWAJACCYMI NA METABOLIZM OOCYTU}

Dla polepszenia stanu mitochondriów próbuje się również stosować suplementację związkami, które stanowia podstawowe elementy i koenzymy w przemianach metabolicznych prowadzonych w mitochondriach lub sa przenośnikami substratów energetycznych. Takie podejście bardzo często w widoczny sposób poprawia metabolizm energetyczny komórek i zabezpiecza przed negatywnym wpływem czasu na kondycję mitochondriów. Dla przykładu, próbuje się wzbogacania diety w koenzym Q10 (CoQ10) pomagajacy $w$ transporcie elektronów poprzez mitochondrialny łańcuch oddechowy. Poziom CoQ10 spada wraz $z$ wiekiem, postuluje się więc, że suplementacja tym zwiazkiem mogłaby usprawnić funkcje mitochondriów w jajnikach (BENTOV i CASPER 2013). Niektóre badania wskazują, że CoQ10, zastosowany w technikach wspomaganego rozrodu, może obniżać poziom aneuploidii w ludzkich oocytach (BENTOV i współaut. 2014), a podawanie tego zwiąku starszym samicom myszy hamuje związana $z$ wiekiem utratę rezerwy jajnikowej, przywraca aktywność mitochondriów i ekspresję genów mitochondrialnych (BEN-MEIR i współaut. 2015). Z kolei suplementacja kwasem a-liponowym (ALA), który jest koenzymem zaangażowanym w metabolizm mitochondriów i znajduje się w wielu roślinach jako naturalny element naszej diety (MOINI i współaut. 2002), zmniejsza poziom RFT i zwiększa żywotność zarodków (YI i MAEDA 2005). Równiė̇ suplementacja L-karnityną, która bierze udział w mitochondrialnym transporcie wolnych kwasów tłuszczowych, może działać protekcyjnie na oocyty poddane technikom mrożeniowym, zapewniajac prawidłowa strukturę wrzeciona podziałowego i właściwe ułożenie mitochondriów wewnatrz oocytu (MOAWAD i współaut. 2014). Inne badania wykazały, że L-karnityna może zwiększać liczbę kopii mtDNA w oocytach owczych, $z$ jednoczesnym zwiększeniem ich kompetencji rozwojowych, znaczaco podnosząc odsetek formujących się blastocyst (READER i współaut. 2015). Innym sposobem polepszenia jakości oocytów w technikach ART jest wykorzystywanie hormonów wzrostu i czynników naturalnie produkowanych przez oocyt. Dla przykładu, dodawanie hormonu wzrostu podczas wywoływania superowulacji podnosi jakość oocytów i ich liczbę u starszych kobiet ze słaba odpowiedzią jajników na hormonalna stymulację (WEALL i współaut. 2015). Z kolei suplementacja BMP15 (ang. bone morphogenetic protein 15), białkiem normalnie produkowanym przez oocyt, może usprawnić funkcjonowanie komórek ziarnistych, polepszajac ich metabolizm (SUTTON-MCDoWALL i współaut. 2012). Dzięki temu zwiększa się wychwyt glukozy przez komórki ziarniste, co umożliwia dostarczanie większych ilości substratów energetycznych do oocytów. Jednocześnie BMP15 poprawia aktywność mitochondriów również w samym oocycie i może podnosić poziom NADPH, a przez to wspomagać utrzymanie prawidłowego poziomu zredukowanego glutationu (GSH), który jest zaangażowany w regulację homeostazy reaktywnych form tlenu (SUTTON-MCDOWALL i współaut. 2015).

Opisane powyżej suplementy stanowia tylko próby niwelowania efektów złego stanu mitochondriów, bacdź też moga być stosowane profilaktycznie odwlekając w czasie występowanie negatywnych skutków mutacji mitochondrialnych. Ponadto skuteczność takiego działania jest często różna w zależności od zastosowanego modelu badawczego. Dlatego próbuje się stosować bardziej inwazyjne metody, które sa w stanie wyeliminować defektywne mitochondria lub zwiększyć proporcję nienaruszonych mitochondriów.

\section{TRANSFER CYTOPLAZMATYCZNY}

Obecnie diagnostyka przedimplantacyjna jest ograniczona w przypadku prób predykcji chorób wynikających $z$ mutacji mtDNA. Jest to spowodowane faktem niemendlowskiego charakteru dziedziczenia schorzeń związanych $z$ mutacjami mtDNA, a także zróżnicowanego poziomu mutacji, przy których pojawiaja się objawy fenotypowe typowe dla chorób o podłożu mitochondrialnym. Ponadto, zjawisko nierównomiernego dziedziczenia mutacji przez oocyty nie pozwala na określenie jakości mitochondrialnego DNA w konkretnych komórkach rozrodczych. Wraz $z$ wiekiem spada też jakość mitochondrialnego genomu w oocytach kobiet oraz zaburzeniu ulegaja mechanizmy eliminacji mutacji, co znacząco pogarsza możliwości uzyskania ciąży po 30 roku życia (BENTOV i CASPER 2013). Dlatego próbuje się "odmładzać” oocyty starszych kobiet, które miały problemy $z$ zajściem $\mathrm{w}$ ciażę, poprzez wstrzykiwanie cytoplazmy $z \mathrm{mi}-$ tochondriami od dawczyń w wieku rozrodczym (BARRITT i współaut. 2001a). Wprawdzie takie działanie znaczaco poprawia jakość oocytów i rozwój zarodków, jednak nie usuwa problemu zmutowanego genomu 
mitochondrialnego w komórce, który wciąż jest przekazywany potomstwu. Po stwierdzeniu heteroplazmii w tkankach płodów i po raportach wskazujacych na nienormalności rozwojowe dzieci, wstrzymano wykonywanie procedury $\mathrm{w}$ wielu krajach (BARRITT i współaut. 2001b). Niedawno technika ta została przywrócona w Wielkiej Brytanii, co budzi obawy o zdrowie dzieci poczętych w wyniku jej stosowania (REINHARDT i współaut. 2013). Groźne konsekwencje dla zdrowia, podczas badań nad heteroplazmia wywołana transferem jąder komórkowych lub iniekcja cytoplazmy, zostały opisane $\mathrm{u}$ wielu gatunków zwierzą, od owadów po małpy człekokształtne (REINHARDT i współaut. 2013). Zastosowanie tego typu technik skutkuje obecnością w jednym organizmie trzech różnych genomów pochodzacych od trojga rodziców (genom mitochondrialny od dwóch matek i genom jądrowy od ojca i jednej z matek), co niesie implikacje etyczne. Dla ominięcia tych problemów oprócz przeszczepów allogenicznych dokonuje się także prób przeszczepów autologicznych, czyli przeszczepu mitochondriów $z$ innego typu komórek osobnika do oocytu, bąź też $z$ jednego oocytu do innego oocytu tego samego osobnika. Niestety wykorzystanie jako dawców komórek innego typu rodzi ryzyko przeniesienia dodatkowych mutacji, ponieważ aktywne metabolicznie komórki somatyczne niosa ze soba wiele mutacji punktowych w mtDNA (BAINES i współaut. 2014). Ponadto, wiele badań wskazuje na pogorszenie się kompetencji rozwojowych oocytów po takich zabiegach, ponieważ funkcje i aktywność mitochondriów sa różne w zależności od typów tkanek, $\mathrm{z}$ których pochodza (KoOPMAn i współaut. 2012). Pomiędzy jadrem komórkowym i mitochondriami istnieje gęsta sieć sygnalizacji wewnattrzkomórkowej, która sprawia, że mitochondria różnych osobników lub pochodzace $z$ różnych tkanek moga reagować w odmienny sposób na sygnały pochodzące $z$ jądra komórkowego oocytu, zagrażając prawidłowemu funkcjonowaniu komórki (CHAPPEL 2013). Wiele badań sugeruje również możliwość wpływu obecności różnych zestawów mitochondriów w jednej komórce na wzór ekspresji samych genów jądrowych (REINHARDT i współaut. 2013). Przypuszcza się, że tworzenie hybrydowych komórek poprzez przeszczepy mitochondriów może, w zależności od zastosowanego modelu badawczego, wpływać na płodność, wzrost, metabolizm i zdolności poznawcze, przy czym objawy te moga być bardzo odsunięte w czasie i pojawić się dopiero $\mathrm{w}$ wieku dorosłym (REINHARDT i współaut. 2013).

\section{KOMÓRKI MACIERZYSTE}

Wielkie nadzieje na możliwość leczenia niepłodności budzą badania nad komórkami macierzystymi. Komórki macierzyste moga okazać się dobrym donorem mitochondriów dla oocytów, ponieważ oba typy komórek wykazuja podobieństwa $\mathrm{w}$ budowie i aktywności tych organelli. Mitochondria komórek macierzystych, podobnie jak oocytów, są okragłe, zawieraja mało grzebieni mitochondrialnych, prowadza ograniczona fosforylację oksydacyjna i produkuja mała ilość wolnych rodników, a same komórki macierzyste $\mathrm{w}$ latwy sposób moga być namnażane $\mathrm{w}$ hodowlach in vitro (SCHATTEN $\mathrm{i}$ współaut. 2014). Wydaje się, że komórki macierzyste wykazuja niższa proporcje zmutowanego mtDNA niż komórki zróżnicowane. Przypuszcza się także, że takie komórki posiadaja bardzo wydajne mechanizmy usuwania heteroplazmii (RAJASIMHA i współaut. 2008). Ponadto, badania wskazuja, że indukowane komórki macierzyste uzyskane z fibroblastów osób obarczonych mutacjami dziela się na dwie subpopulacje, $z$ których jedna posiada zmutowany mtDNA, a druga jest całkowicie od niego wolna. Pozwala to uzyskać klony indukowanych komórek macierzystych całkowicie pozbawionych zmutowanego mtDNA (Folmes i współaut. 2013). Może to sugerować obecność mechanizmów segregujacych zmutowane DNA podczas przeprogramowania komórek, co otwierałoby nowe możliwości dla autologicznych przeszczepów komórek macierzystych w chorobach mitochondrialnych lub przeszczepów samych mitochondriów w technikach wspomaganego rozrodu.

Uważa się, że jajniki dorosłych ssaków zawierają pewna ilość niezróżnicowanych multipotentnych komórek macierzystych ulokowanych w powierzchniowym nabłonku jajnika, które przypominaja pierwotne prekursory komórek płciowych, a także tzw. małe embrionalno-podobne komórki macierzyste VSELs (ang. very small embryonic-like cells). Oba typy komórek moga się różnicować w hodowlach in vitro $\mathrm{w}$ komórki przypominajace oocyty (GHEORGHISAN-GalateAnU i współaut. 2014). Tego typu komórki mogłyby więc stanowić źródło dobrej jakości mitochondriów wykorzystywanych do przeszczepów autologicznych.

Wciąz trwa intensywna debata na temat komórek macierzystych jajnika. Nie wiadomo czy te komórki pochodza bezpośrednio $z$ jajnika, czy czasowo do niego migruja, oraz czy są komórkami pierwotnie niezróżnicowanymi, czy też komórkami, które uległy odróżnicowaniu w wieku dorosłym. Niektórzy badacze dopuszczają także możliwość uzyskania 
w przyszłości zdrowych oocytów z komórek macierzystych hodowanych in vitro lub odnowy rezerwy jajnikowej przy ich pomocy (GHEORGHISAN-GALATEANU i współaut. 2014). Dokonanie takiego zabiegu u ludzi, jeśli w ogóle jest możliwe, wymagać będzie jednak lat badań nad ustaleniem odpowiednich warunków różnicowania takich komórek oraz badań ich statusu epigenetycznego i innych wyznaczników bezpieczeństwa stosowania komórek rozrodczych uzyskiwanych taka metoda.

\section{TRANSFER JĄDROWY}

Obecnie dokonuje się prób ominięcia problemu obecności dwóch zestawów mitochondriów w oocycie (prawidłowych i zmutowanych) poprzez przeszczepy samych jąder komórkowych komórek dawczyń do pozbawionego jądra komórkowego oocytu biorczyni o zdrowym genomie mitochondrialnym. Dzięki temu nosiciele poważnych mutacji moga mieć własne dzieci bez chorób mitochondrialnych. Badania wskazuja jednak, że około $1 \%$ mitochondriów może zostać przeniesiony do komórki biorczyni wraz $z$ jądrem komórkowym (PAULL i współaut. 2013). Pomimo że poziom mutacji, przy którym pojawiają się typowe symptomy chorób mitochondrialnych, wynosi zwykle około 60\% (SCHON i współaut. 2012), to niektóre badania wskazuja na możliwość pojawienia się poważnych chorób mitochondrialnych przy niższym poziomie zmutowanego mtDNA, wynoszacym nawet poniżej 2\% (SCHON i współaut. 2012). Dlatego próbuje się udoskonalać procedury przeszczepu jadrowego materiału genetycznego, minimalizując ilość przenoszonej wraz $z$ nim cytoplazmy, zawierającej uszkodzone mitochondria (CRAVEN i współaut. 2011). Jedna $z$ dróg rozwiazania tego problemu jest transfer wrzeciona podziałowego wraz $z$ chromosomami w stadium metafazy II, co zostało wykazane na małpach człekokształtnych (TACHIBANA i współaut. 2009). Transfer taki minimalizuje ilość przeniesionej cytoplazmy, ponieważ wrzeciono podziałowe znajduje się bliżej błony komórkowej oocytu, umożliwiajac pobranie mniejszego karioplastu (protoplastu zawierającego jądro komórkowe $z$ minimalną ilościa cytoplazmy i błona cytoplazmatyczna). Dodatkowo techniki transferu wrzeciona podziałowego nie wymagaja stosowania inhibitorów polimeryzacji tubuliny, koniecznych podczas transferu przedjądrzy między zygotami, a jedynie inhibitorów szkieletu aktynowego oocytu (CRAVEn i współaut. 2011). Mimo tego, uszkodzenia wrzeciona podziałowego podczas procedury moga skutkować nieprawidłowym rozejściem się chromosomów do komórek potomnych i aneuploidami u potomstwa, na co wskazuja niektóre badania (TACHIBANA i współaut. 2013).

Inna proponowana technika jest transfer przedjądrzy lub jacder komórkowych na etapie zygoty. W tym jednak przypadku obserwowano stosunkowo mały odsetek formujacych się blastocyst (spadek o 50\%) oraz dużą ilość zmutowanego mtDNA przenoszonego wraz $z$ jądrami komórkowymi, co sprawia, że wciąż obserwowano około $2 \% \mathrm{zmu}-$ towanych cząsteczek mtDNA w porównaniu $z$ około 35\% zmutowanego mtDNA, występującego u dawczyni jądra komórkowego (CRAVEN i współaut. 2010). Oprócz tego, przy stosowaniu takiej techniki u ludzi obserwuje się obniżenie kompetencji rozwojowych zygot i pojawianie się wielobiegunowych wrzecion podziałowych (EGLI i współaut. 2011).

Rozważanym od niedawna i bardzo obiecujacym rozwiazaniem jest stosowanie ciałka kierunkowego jako donora jądrowego materiału genetycznego. Wynika to $z$ obserwacji, iż oocyty posiadaja mechanizm zabezpieczajacy przed trafianiem mitochondriów do pierwszego ciałka kierunkowego (PB1), a podczas drugiego podziału mejotycznego, mimo braku takiego mechanizmu, liczba mitochondriów przekazanych do drugiego ciałka kierunkowego (PB2) jest znikoma (DALTON i CARROLL 2013). WANG i współaut. (2014) dokonali porównania technik transferu wrzeciona podziałowego $z$ chromosomami pomię$\mathrm{dzy}$ oocytami w metafazie II, analogicznego transferu wrzeciona podziałowego $z$ pierwszego ciałka kierunkowego (PB1) do oocytu $\mathrm{w}$ stadium metafazy II, transferu przedjądrzy pomiędzy zygotami i jądra komórkowego drugiego ciałka kierunkowego (PB2) do zygoty pozbawionej przedjądrza żeńskiego. W zestawieniu tym największy odsetek potomstwa $z$ heteroplazmia obserwowano przy technikach transferu przedjądrzy, bardzo mały odsetek heteroplazmii był wykrywany po transferze jądra PB2 i niewykrywalny po transferze wrzeciona PB1. Dlatego według autorów transfer genomu ciałka kierunkowego daje dużo niższa odziedziczalność mutacji mitochondrialnych niż transfer wrzeciona podziałowego czy przedjądrzy. Stosowanie technik transferu jąder daje nadzieję na posiadanie potomstwa przez kobiety obarczone mutacjami mtDNA oraz przez osoby w starszym wieku. Pomimo że sa to to techniki niezwykle inwazyjne i kontrowersyjne, to wiele badań prowadzonych na blisko spokrewnionych $z$ człowiekiem małpach człekokształtnych dowodzi braku wad rozwojowych po ich zastosowaniu (TACHIBANA i współaut. 2014). Sugeruje się jednak, że ludzkie oocyty moga posiadać bardziej wrażliwe na mikromanipulacje wrzeciona podziałowe, któ- 
re łatwiej ulegają uszkodzeniom podczas transferu niż wrzeciona innych naczelnych. Ponadto obserwuje się przypadki aktywacji uzyskanych tą drogą oocytów jeszcze przed zapłodnieniem i powstawanie aneuploidalnych zarodków (TACHIBANA i współaut. 2013). Dlatego techniki transferu materiału genetycznego wymagaja dalszych badań i optymalizacji ich stosowania w przypadku ludzi.

\section{CELOWANE USUWANIE ZMUTOWANEGO MTDNA}

Aktualnie bardzo obiecujaca i intensywnie rozwijana metoda pozwalająca na usunięcie mutacji $z$ komórek jest zastosowanie enzymów restrykcyjnych specyficznie rozpoznajacych zmutowany mtDNA. Metoda ta zakłada wykorzystanie specjalnie zaprojektowanego enzymu restrykcyjnego, który rozpozna zmutowana sekwencję, dokona cięcia mtDNA w mitochondriach niosacych mutację i zablokuje ich replikację, natomiast nie wywoła żadnych skutków w prawidłowym mtDNA. Pierwszą udana próbą tego typu było wykorzystanie białek $\mathrm{z}$ motywem palca cynkowego ZFPs (ang. custom-designed zinc finger nucleases). Białka tego rodzaju moga być zaprojektowane do rozpoznawania i wiazania specyficznych sekwencji DNA, a po fuzji tych białek ze specyficznymi endonukleazami moga dokonywać cięć nici DNA w sekwencjach rozpoznanych przez enzym jako wadliwe. MinCZUK i współaut. (2008) zaprojektowali ZFP rozpoznajace punktowa mutację substytucji guaniny na cytozynę $\mathrm{w}$ pozycji 8993 mtDNA (8993T>G), która odpowiada za występowanie syndromu Leigha i NARP. Następna generacja tego typu terapii stały się nukleazy TALEs (ang. transcription activator-like effectors), które, podobnie jak ZFPs, moga być projektowane do rozpoznawania specyficznych sekwencji genomu i ograniczać się tylko do genomu mitochondrialnego (BoCH i współaut. 2009). Białka TALE to grupa białek występujących naturalnie $\mathrm{w}$ infekujacych rośliny bakteriach Xanthomonas i sa $\mathrm{w}$ stanie wiazać się ze specyficznymi DNA, zmieniajac ekspresję genów roślinnych. Białka TALE zawieraja podjednostki składające się z 34 aminokwasów każda, przy czym 32 aminokwasy sa takie same, a aminokwasy $\mathrm{w}$ pozycji 12 i 13 sa zmienne i odpowiadaja za rozpoznawanie specyficznego nukleotydu $\mathrm{w}$ nici DNA. Dlatego podjednostki w latwy sposób można dobierać, tak by rozpoznawały określona sekwencję DNA. Dodatkowo okazało się, że białka TALE można połączyć $z$ nukleazami Fok tworzac fuzyjne białka, które sa $\mathrm{w}$ stanie dokonać rozpoznania i cięcia określonej sekwencji DNA. W ten sposób powstała rodzina białek TALENs (ang. TALE nucleases) (NEMUDRYI i współaut. 2014), które cechuja się znacznie prostszą budowa domeny wiażącej DNA niż białka $z$ motywem ZFP, a co za tym idzie większa łatwościa ich modyfikacji (SEga i LinKIEwICZ 2014). Do pierwszej próby usunięcia uszkodzonych mitochondriów $z$ wykorzystaniem TALENs wykorzystano często występujaca delecję, obejmujacą fragment o długości $4977 \mathrm{bp}$ pomiędzy pozycjami 8470 i 13,477 mitochondrialne-

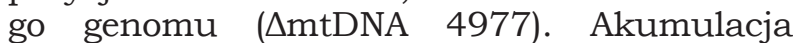
tej mutacji jest obserwowana w starych i niedzielących się tkankach, włączając $\mathrm{w}$ to jajniki, a także jest obserwowana w dużej liczbie w oocytach, które nie uległy zapłodnieniu. Dlatego mutacja $\triangle$ mtDNA4977 jest markerem starzenia się, a co najważniejsze może być przekazywana potomstwu (CHAN i współaut. 2006).

Pierwsza próbę usunięcia mitochondriów $z$ delecja $4977 \mathrm{bp}$ przeprowadzono na liniach komórek somatycznych. Dwie cząsteczki TALENs zostały tak zaprojektowane, by jedna zmogła łaczyć się ze specyficzna sekwencja $\mathrm{w}$ pobliżu pozycji $8470 \mathrm{mtDNA}$, natomiast druga $w$ pobliżu sekwencji 13,477 mtDNA. Tylko w przypadku wystapienia delecji, a więc braku sekwencji o długości 4977bp pomiędzy pozycjami 8470 i 13,477, możliwe było zbliżenie obu czasteczek TALENs, pozwalajace na dimeryzajce endonuklezay Fok I i dokonanie cięcia nici mtDNA (BACMAN i współaut. 2013). Próba wykorzystania metody zaowocowała zmniejszeniem heteroplazmii z $70 \%$ do $30 \%$ przy jednoczesnym braku negatywnego wplywu na zdrowy mtDNA oraz bez wpływu na liczbę komórek w hodowli (BACMAN i współaut. 2013). Dwa lata później dokonano pierwszej próby usunięcia heteroplazmii za pomoca TALENs $z$ oocytów myszy. W tym celu stworzono heteroplazmatyczne oocyty zawierajace mitochondria o dwóch haplotypach pochodzacych ze szczepów myszy BALB i NZB. Po wstrzyknięciu mRNA kodujacego TALENs udało się specyficznie usunać wybrany haplotyp mitochondriów $z$ oocytów zabezpieczając przed przekazaniem go potomstwu (REDDY i współaut. 2015). W celu określenia, czy enzymy tego rodzaju moga być używane do edycji ludzkiego mtDNA badacze dokonali fuzji oocytów myszy $z$ komórkami fibroblastów pacjentów o jednym $z$ dwóch zaburzeń mitochondrialnych - dziedzicznej neuropatii nerwu wzrokowego Lebera (LHON) i neurogennej miopatii $z$ ataksja i zwyrodnieniem barwnikowym siatkówki (NARP). W tym przypadku zmutowany genom nie został wyeliminowany całkowicie, ale drastycznie zmniejszono jego ilość w hybrydowych komórkach (REDDY i 
współaut. 2015). Obecnie poszukuje się takich wektorów, które mogłyby dostarczać TALENs do wielu typów komórek (także dorosłego osobnika) bez konieczności bezpośredniego wstrzykiwania mRNA do komórek (LIU i współaut. 2014, Mock i współaut. 2014). Daje to nadzieje na złagodzenie lub wyleczenie wielu chorób mitochondrialnych, a także spowolnienie procesów starzenia, również w komórkach linii płciowej, bez konieczności manipulacji tymi komórkami in vitro.

\section{PODSUMOWANIE}

W ostatnim dziesięcioleciu poczyniono duże postępy w opracowywaniu potencjalnych terapii majacych na celu poprawę jakości oocytów. Tego rodzaju terapie daja nadzieje na polepszenie płodności kobiet $z$ zaburzeniami metabolicznymi takimi jak otyłość, cukrzyca czy zmiany zwiąane ze starzeniem się. Tego rodzaju zaburzenia odbijana się głównie na jakości mitochondriów, a więc organelli zwiazanych $z$ zaspokajaniem zapotrzebowania energetycznego oocytu w tak ważnych dla jego funkcjonowania procesach, jak formowanie się wrzeciona podziałowego i podziały mejotyczne Szacuje się, że w 15-20\% oocytów dochodzi do nieprawidłowego rozejścia się chromosomów (PELLESTOR i współaut. 2005), a około 5\% ludzkich zarodków posiada aneuploidie, przy czym problem ten nasila się $z$ wiekiem matki (HASSOLD i HuNT 2001). Uważa się, że za ten stan może odpowiadać obniżenie jakości mitochodriów, spadek liczby kopii mtDNA i poziomu ATP w oocycie (BABAYEV i SELI 2015). Oprócz tego pojawiajace się w oocytach mutacje mitochondrialne moga być dziedziczone i przez to wpływać na jakość życia potomstwa (WU i współaut. 2015). Jako główne czynniki odpowiedzialne za zaburzenia i nieprawidłowości zwiąane $z$ funkcjonowaniem mitochondriów wymienia się: niezdrowy styl życia, choroby cywilizacyjne jak otyłość, cukrzyca, a także palenie tytoniu (GRINDLER i MOLEY 2013). Wielu tych problemów można uniknać zmieniając styl życia i utrzymujacc prawidłowa dietę, a utrzymanie odpowiedniej jakości pokarmu, bogatego w witaminy, koenzymy czy przeciwutleniacze, skutecznie odwleka w czasie zwiazany $z$ wiekiem spadek jakości mitochondriów i samych oocytów. Sa to jednak metody głównie profilaktyczne i wymagajace długiego stosowania. Alternatywę stanowia bardziej inwazyjne sposoby usuwania defektów mitochondrialnych $z$ oocytów, jak transfer mitochondriów, transfer jacdrowego materiału genetycznego, metody edytowania genomu, a w przyszłości być może również uzyskiwanie funkcjo- nalnych gamet $z$ komórek macierzystych. Metody te, pomimo szybkich i często obiecujących efektów, obarczone sa jednak ryzykiem skutków ubocznych. Można tu wymienić chociażby trudne do przewidzenia skutki funkcjonowania różnych zestawów mitochondriów w jednej komórce pochodzacych $z$ oocytu i różnych typów komórek dawczyń, uszkodzenia mechaniczne podczas inwazyjnych metod transferu materiału genetycznego, czy ryzyko wprowadzenia nowych mutacji (poza sekwencjami, które miały „uleczyć”) w technikach edytowania genomu (SCHAEFER i współaut. 2017). Omówione terapie sa również stosunkowo nowe i słabo przebadane, a do tego budza problemy natury etycznej. Ponieważ stosowanie tego rodzaju technik może rzutować na jakość życia nie tylko matki, ale również potomków, powinno się podchodzić do nich $z$ dużą ostrożnością. Dlatego, pomimo że maja szansę rozwiazać wiele problemów zwiazanych $z$ niepłodnościa człowieka, powinny być szeroko przebadane pod kątem bezpieczeństwa ich stosowania $u$ ludzi zanim zostana rutynowo wykorzystywane w klinikach leczenia niepłodności.

\section{STRESZCZENIE}

Linia żeńskich komórek płciowych jest zasadniczo nieśmiertelna linia komórkowa, która przekazuje haploidalny genom jadrowy $\mathrm{i}$ pełen genom mitochondrialny kolejnym pokoleniom. Współwystępowanie w komórce zmutowanych kopii mtDNA i prawidłowego mtDNA określane jest jako heteroplazmia $\mathrm{i} w$ zależności od typu mutacji oraz od liczby zmutowanych kopii mtDNA stanowi źródło wielu chorób wieku dorosłego. Uważa się, że genom mitochondrialny może podlegać naturalnym mechanizmom oczyszczającym go ze zgromadzonych mutacji. Efektywność tych procesów może być jednak niewystarczająca, skutkując dużą proporcja nieprawidłowości o podłożu mitochondrialnym w ludzkiej populacji. Dlatego poszukuje się metod, które mogłyby polepszyć ich jakość, a także odwlec w czasie niekorzystne procesy starzenia, które w negatywny sposób odbijaja się zarówno na jakości mitochondrialnego genomu, jak i samej płodności ssaków.

\section{LITERATURA}

Acuna-Hidalgo R., Veltman J. A., Hoischen A., 2016. New insights into the generation and role of de novo mutations in health and disease. Genome Biol. 1-19.

AMARAL S., Oliveira P. J., RAMalho-Santos J., 2008. Diabetes and the impairment of reproductive function: possible role of mitochondria and reactive oxygen species. Curr. Diabetes Rev. 4, 46-54.

BABAYEV E., Seli E., 2015. Oocyte mitochondrial function and reproduction. Curr. Opin. Obstet. Gynecol. 27, 175-181.

Bacman S. R., Williams S. L., Pinto M., Peralta S., MORAES C. T., 2013. Specific elimination of mutant mitochondrial genomes in patient-derived cells by mitoTALENs. Nat. Med. 19, 11111113. 
BAHADORI M. H., GHASEMian F., RAMEZANi M., AsGARI Z., 2013. Melatonin effect during different maturation stages of oocyte and subsequent embryo development in mice. Iran. J. Reprod. Med. 11, 11-18.

Baines H. L., Turnbull D. M., Greaves L. C., 2014. Human stem cell aging: do mitochondrial DNA mutations have a causal role? Aging Cell 13, 201-205.

BAird D. T., COllins J., EgOzCue J., Evers L. H., Gianaroli L., Leridon H., Sunde A., TemPleton A., VAN STEIRTEGHEM A., COHEN J. współaut., 2005. Fertility and ageing Hum. Reprod. Update 11, 261-276.

BARRITT J. A., BREnNer C. A., MAlter H. E. COHEN J., 2001a. Mitochondria in human of fspring derived from ooplasmic transplantation: Brief communication Hum. Reprod. 16, 513516.

BARRITT J. A., BREnNer C. A., MAlter H. E., COHEN J., 2001b. Rebuttal: interooplasmic trans fers in humans. Reprod. Biomed. Online 3, 47-48.

Ben-Meir A., Burstein E., Borrego-Alvarez A., CHONG J., WONG E., YAVORSKA T., NARANIAN T., ChI M., WANG Y., BENTOV Y., AleXIS J., Meriano J., Sung H.-K., Gasser D. L., Moley K. H., HEKIMI S., CASPER R. F., JuRISICOVA A., 2015. Coenzyme Q10 restores oocyte mitochondrial function and fertility during reproductive aging. Aging Cell 14, 887-895.

BENTOV Y., CASPER R. F., 2013. The aging oocyte--can mitochondrial function be improved? Fertil. Steril. 99, 18-22.

BENTOV Y., HANNAM T., JURISICOVA A., ESFANDIAR N., CASPER R. F., 2014. Coenzyme Q10 supplementation and oocyte aneuploidy in women undergoing IVF-ICSI treatment. Clin. Med. Insights. Reprod. Heal. 8, 31-36.

BOCH J., SCHOLZE H., SCHORNACK S., LANDGRAF A., Hahn S., Kay S., lahaye T., Nickstadt A. BONAS U., 2009. Breaking the code of DNA binding specificity of TAL-type III effectors. Science 326, 1509-1512.

BOUdOURES A. L., SABEN J., DRURY A., SCHEAFFER S., MOdi Z., ZHANG W., MOley K. H., 2017. Obesity-exposed oocytes accumulate and transmit damaged mitochondria due to an inability to activate mitophagy. Dev. Biol. 426, 126-138.

Chan C. C., W., LiU V. W. S., LaU E. Y. L., YeunG W. S. B., NG E. H. Y., HO P. C., 2006. Mitochondrial DNA content and 4977 bp deletion in unfertilized oocytes. Mol. Hum. Reprod. $11,843-846$.

CHAPPEL S., 2013. The role of mitochondria from mature oocyte to viable blastocyst. Obstet. Gynecol. Int. 2013, 183024.

Combelles C. M. H., Gupta S., Agarwal A. 2009. Could oxidative stress influence the in -vitro maturation of oocytes? Reprod. Biomed. Online 18, 864-880.

Craven L., Tuppen H. A., Greggains G. D., Harbottle S. J., Murphy J. L., CREe L. M., MurDOCH A. P., ChINNERY P. F., TAYLOR R. W., LIGHTOWLERS R. N., HERBERT M., TURNBULL D M., 2010. Pronuclear transfer in human embryos to prevent transmission of mitochondrial DNA disease. Nature 465, 82-85.

Craven L., Elson J. L., IRVing L., TupPen H. A., Lister L. M., GREgGains G. D., BYerley S., Murdoch A. P., Herbert M., Turnbull D., 2011. Mitochondrial DNA disease: new options for prevention. Hum. Mol. Genet. 20, R168$-\mathrm{R} 174$.
DaI Y., Zheng K., Clark J., SWERDlOW R. H., PUlst S. M., SUtTON J. P., SHINOBU L. A., SIMON D. K., 2014. Rapamycin drives selection against a pathogenic heteroplasmic mitochondrial DNA mutation. Hum. Mol. Genet. 23, 637-647.

Dalton C. M., CARroll J., 2013. Biased inheritance of mitochondria during asymmetric cell division in the mouse oocyte. J. Cell Sci. 126, 2955-2964.

Diot A., Dombi E., Lodge T., LiaO C., Morten K., Carver J., Wells D., Child T., Johnston I. G., Williams S., POUlToN J., 2016. Modu lating mitochondrial quality in disease transmission: towards enabling mitochondrial DNA disease carriers to have healthy children. Biochem. Soc. Trans. 44, 1091-1100.

Duleba A. J., Foyouzi N., Karaca M., PEHLIVAN T., KwINTKIEWICZ J., BEHRMAN H. R., 2004. Proliferation of ovarian theca-interstitial cells is modulated by antioxidants and oxidative stress Hum. Reprod. 19, 1519-1524.

Egli D., Chen A. E., Saphier G., ICHIDA J., FitZGerald C., Go K. J., ACevedo N., PATel J., BAETSCHER M., KEARNS W. G., Goland R., LEIBEL R. L., MELTON D A., EgGAN K., 2011. Reprogramming within hours following nuclear transfer into mouse but not human zygotes. Nat. Commun. 2, 488.

El-Raey M., Geshi M., Somfai T., Kaneda M., HiRAKO M., ABDEl-GhafFAR A. E., SOSA G. A., El-Roos M. E. A. A., NAGAI T., 2011. Evidence of melatonin synthesis in the cumulus oocyte complexes and its role in enhancing oocyte maturation in vitro in cattle. Mol. Reprod. Dev. 78, 250-262.

ElliotT H. R., SAMuels D. C., Eden J. A., RelTON C. L., ChINNERY P. F., 2008. Pathogenic mitochondrial DNA mutations are common in the general population. Am. J. Hum. Genet. $83,254-260$.

Folmes C. D. L., MartineZ-Fernandez A., Perales-Clemente E., Li X., McDonald A., OGlesBeE D., Hrstka S. C., Perez-Terzic C., TERZIC A., NELSON T. J., 2013. Disease-causing mitochondrial heteroplasmy segregated within induced pluripotent stem cell clones derived from a patient with MELAS. Stem Cells 31, 1298-1308.

Gheorghisan-Galateanu A., A., Hinescu M., E., ENCIU A., M., 2014. Ovarian adult stem cells: hope or pitfall? J. Ovarian Res. 7, 71.

GiLKerson R. W., DE VRIES R. L. A., LEBOT P., WikSTROM J. D., TORGYEKES E., SHIRIHAI O. S., PRZEDBORSKI S., SCHON E. A., 2012. Mitochondrial autophagy in cells with mtDNA mutations results from synergistic loss of transmembrane potential and mTORC1 inhibition. Hum. Mol. Genet. 21, 978-990.

GREENSTEIN D., 2005. Control of oocyte meiotic maturation and fertilization. WormBook, doi:10.1895/wormbook.1.53.1.

GREgG S. Q., GUTIÉRREZ V., RoBINSON A. R., WOODEll T., NAKAO A., ROSS M. A., MIchalopoulos G. K., RigatTi L., Carrie E., KaMILERI I., GARINIS G., STOLZ D. B., LAURA J., 2013. A mouse model of accelerated liver ag ing due to a defect in DNA repair. Hepatology $55,609-621$

GrindleR N. M., MOley K. H., 2013. Maternal obesity, infertility and mitochondrial dysfunction: potential mechanisms emerging from mouse model systems. Mol. Hum. Reprod. 19, 486-494.

HARRISON D. E., STRONG R., SHARP Z. D., NELSON J. F., ASTle C. M., FluRKey K., NADON 
N. L., Wilkinson J. E., Frenkel K., Carter C. S., PAHOR M., JAVORS M. A., FERNANDEZ E., MILLER R. A., 2009. Rapamycin fed late in life extends lifespan in genetically heterogeneous mice. Nature 460, 392-395.

Hassold T., HunT P., 2001. To err (meiotically) is human: the genesis of human aneuploidy. Nat. Rev. Genet. 2, 280-291.

HoEIJMAKERS J. H. J., 2009. DNA damage, aging, and cancer. N. Engl. J. Med. 361, 14751485.

IKEDA Y., SCIARRETTA S., NAGARAJAN N., RUBATTU S., VolPe M., Frati G., SADOShima J., 2014. New Insights into the Role of Mitochondrial Dynamics and Autophagy during Oxidative Stress and Aging in the Heart. Oxid. Med. Cell. Longev. 2014, 210934.

Jenwitheesuk A., Nopparat C., Mukda S., WongCHITRAT P., GOVITRAPONG P., 2014. Melatonin regulates aging and neurodegeneration through energy metabolism, epigenetics, autophagy and circadian rhythm pathways. Int. J. Mol. Sci. 15, 16848-16884.

KAWAMURA Y., UCHIJIMA Y., HORIKE N., TONAMI K., Nishiyama K., Amano T., Asano T., KurIHARA Y., KURIHARA H., 2010. Sirt3 protects in vitro-fertilized mouse preimplantation embryos against oxidative stress-induced p53-mediat ed developmental arrest. J. Clin. Invest. 120, 2817-2828.

KENYON C. J., 2010. The genetics of ageing. Nature 464, 504-512.

KHRAPKO K., TURNBULL D., 2014. Mitochondrial DNA mutations in aging. Prog. Mol. Biol. Transl. Sci. 127, 29-62.

KoOPMAN W. J. H., WILlEMS P. H. G. M., SMEITINK J. A., M., 2012. Monogenic mitochondrial disorders. N. Engl. J. Med. 366, 1132-1141.

LARSSON N.-G., 2010. Somatic mitochondrial DNA mutations in mammalian aging. Annu. Rev. Biochem. 79, 683-706.

LeE S. E., KiM E. Y., ChOI H. Y., MOON J. J., PARK M. J., LEE J. B., JEONG C. J., PARK S. P., 2014. Rapamycin rescues the poor developmental capacity of aged porcine oocytes. Asian-Australasian J. Anim. Sci. 27, 635-647.

LetTieri Barbato D., Baldelli S., PAGLiei B., AQUilano K., CiRIOlO M. R., 2012. Caloric restriction and the nutrient-sensing PGC-1a in mitochondrial homeostasis: New perspectives in neurodegeneration. Int. J. Cell Biol. 2012, $1-11$.

Li P., LIANG M.-L., ZHU Y., GONG Y.-Y., WANG Y., HENG D., LIN L., 2014. Resveratrol inhibits collagen I synthesis by suppressing IGF-1R activation in intestinal fibroblasts. World J. Gastroenterol. 20, 4648-4661.

LIM J., LUDERER U., 2011. Oxidative damage increases and antioxidant gene expression decreases with aging in the mouse ovary. Biol. Reprod. 84, 775-782.

Linnane A W., MarzUKI S., Ozawa T., TANAKa M., 1989. Mitochondrial DNA mutations as an important contributor to ageing and degenerative diseases. Lancet 1, 642-645.

LIU J., GAJ T., PATTERSON J. T., SIRK S. J., BARBAS C. F., 2014. Cell-penetrating peptide-mediated delivery of TALEN proteins via bioconjugation for genome engineering. PLoS One 9, e85755.

LorD T., NiXon B., Jones K. T., Aitken R. J., 2013. Melatonin prevents postovulatory oocyte aging in the mouse and extends the window for optimal fertilization in vitro. Biol. Reprod. $88,67$.
Luke B., BROWN M. B., STERN J. E., MisSMeR S. A., FUJIMOTO V. Y., LEACH R., SART WRITING GROUP, 2011. Female obesity adversely affects assisted reproductive technology (ART) pregnancy and live birth rates. Hum. Reprod. $26,245-252$.

Luzzo K. M., Wang Q., Purcell S. H., ChI M., Jimenez P. T., Grindler N., SchedL T., MoLEY K. H., 2012. High fat diet induced developmental defects in the mouse: oocyte meiotic aneuploidy and fetal growth retardation/brain defects. PLoS One 7, e49217.

MARLOW F. L., 2017. Mitochondrial matters: Mitochondrial bottlenecks, self-assembling structures, and entrapment in the female germline. Stem Cell Res. 21, 178-186.

MinczuK M., PAPWORTH M. A., Miller J. C., MurPHY M. P., KLUG A., 2008. Development of a single-chain, quasi-dimeric zinc-finger nuclease for the selective degradation of mutated human mitochondrial DNA. Nucleic Acids Res. 36, 3926-3938.

MinOR R. K., AllaRD J. S., YOUnTS C. M., WARD T. M., DE CABO R., 2010. Dietary interventions to extend life span and health span based on calorie restriction. J. Gerontol. A. Biol. Sci. Med. Sci. 65, 695-703.

MOAWAD A. R., XU B., TAN S. L., TAKETO T., 2014. l-carnitine supplementation during vitrification of mouse germinal vesicle stage-oocytes and their subsequent in vitro maturation improves meiotic spindle configuration and mitochondrial distribution in metaphase II oocytes. Hum. Reprod. 29, 2256-2268.

Mock U., RIECKEN K., BERDIEN B., QASIM W., Chan E., CATHOMEN T., FEHSE B., 2014. Novel lentiviral vectors with mutated reverse transcriptase for MRNA delivery of TALE nucleases. Sci. Rep. 4, 6409.

Moini H., Packer L., Saris N.-E., L., 2002. Antioxidant and prooxidant activities of alpha-lipoic acid and dihydrolipoic acid. Toxicol. Appl. Pharmacol. 182, 84-90.

Moskalev A. A. Shaposhnikov M. V. Plyusnina E. N., Zhavoronkov A., Budovsky A., YANAI H., FRAIFELD V. E., 2013. The role of DNA damage and repair in aging through the prism of Koch-like criteria. Ageing Res. Rev. 12, 661684.

MOUCHIROUd L., HouTKOOPER R. H., MOUllan N., KATSYUBa E., RYU D., CANTÓ C., MOTTIS A., JO Y.-S., VISWANATHAN M., SCHOONJANS K., GUARENTE L., AUWERX J., 2013. The NAD(+)/ sirtuin pathway modulates longevity through activation of mitochondrial UPR and FOXO signaling. Cell 154, 430-441.

Murga M., Bunting S., Montaña M. F., Soria R., Mulero F., CAÑAMERO M., LEe Y., MCKINNON P. J., NUSSENZWEIG A., 2010. A mouse model of the ATR-Seckel Syndrome reveals that replicative stress during embryogenesis limits mammalian lifespan. Nat Genet. 41, 891-898.

MuRShID A., EGUCHI T., CALDERWOOD S. K., 2013. Stress proteins in aging and life span. Int. J. Hyperthermia 29, 442-447.

Nemudry A. A., VAlETdinOVA K. R., MedVedeV S. P., ZAKIAN S. M., 2014. TALEN and CRISPR/ Cas genome editing systems: Tools of discovery. Acta Naturae 6, 19-40.

Ou X.-H., LI S., WANG Z.-B., LI M., QuAN S., Xing F., Guo L., ChaO S.-B., Chen Z., Liang X.-W., Hou Y., SchatTEN H., SuN Q.-Y., 2012. Maternal insulin resistance causes oxidative stress and mitochondrial dysfunction in mouse oocytes. Hum. Reprod. 27, 2130-2145.

in vitro. Biores. Open Access 3, 183-191. 
Paull D., Emmanuele V., Weiss K. A., Treff N., STEWART L., HUA H., ZIMMER M., KAHLER D. J., Goland R. S., Noggle S. A., PRosser R., Hirano M., Sauer M., V Egli D., 2013. Nuclear genome transfer in human oocytes eliminates mitochondrial DNA variants. Nature 493, 632-637.

PEllestor F., ANAHory T., Hamamah S., 2005. Effect of maternal age on the frequency of cytogenetic abnormalities in human oocytes Cytogenet. Genome Res. 111, 206-212.

RAJASIMHA H. K., ChinNerY P. F., SAMUEls D. C. 2008. Selection against pathogenic mtDNA mu tations in a stem cell population leads to the loss of the 3243A-->G mutation in blood. Am. J. Hum. Genet. 82, 333-343.

READER K. L., COX N. R., STANTON J.-A. L., JUENGEL J. L., 2015. Effects of acetyl-L-carnitine on lamb oocyte blastocyst rate, ultrastructure, and mitochondrial DNA copy number. Theriogenology 83, 1484-1492.

REDDY P., OCAMPO A., SUZUKI K., LUO J., BACMAN S. R., Williams S. L., Sugawara A., OKamuRA D., TSuneKawa Y., WU J., LAM D., XIONG X. MONTSERRAT N. i współaut., 2015. Selective elimination of mitochondrial mutations in the germline by genome editing. Cell 161, 459469.

REINHARDT K., DOWLING D. K., MoRRow E. H., 2013. Medicine. Mitochondrial replacement, evolution, and the clinic. Science 341, 13451346.

Ruder E. H., Hartman T. J., Blumberg J., GoldMAN M. B., MANUSCRIPT A., 2009. Oxidative stress and antioxidants: exposure and impact on female fertility. Hum. Reprod. Update 14 , 345-357.

Sato D., Itami N., TASaki H., TAKeO S., KuwaYAMA T., IWATA H., 2014. Relationship between mitochondrial DNA copy number and SIRT1 expression in porcine oocytes. PLoS One 9, e94488.

Schaefer K. A., Wu W.-H., Colgan D. F., Tsang S. H., BASSUK A. G., MAHAJAN V. B., 2017. Unexpected mutations after CRISPR-Cas9 editing in vivo Nat. Methods 14, 547-548.

SCHATTEN H., SUN Q., PRATHER R., 2014. Mitochondrial differentiation in early embryo cells and pluripotent stem cells. [W:] Cell and mololecular biology and imaging of stem cells. SCHATTEN H. (red.). Cell Mol. Biol., 247-258.

Schon E., A., DiMauro S., Hirano M., 2012. Human mitochondrial DNA: roles of inherited and somatic mutations. Nat. Rev. Genet. 13, 878890.

SEGA P., LinkieWICZ A., 2014. Wykorzystanie miejscowo-specyficznych nukleaz do modyfikacji genomów roślinnych. Adv. in Cell Biol. 4, 701-720.

Selesniemi K., Lee H.-J., Muhlhauser A., Tilly J. L., 2011. Prevention of maternal aging-associated oocyte aneuploidy and meiotic spindle defects in mice by dietary and genetic strategies. Proc. Natl. Acad. Sci. USA 108, 1231912324.

SutTON-MCDowall M. L., MotTershead D. G., GARDNER D. K., GILCHRIST R. B., THOMPSON J. G., 2012. Metabolic differences in bovine cumulus-oocyte complexes matured in vitro in the presence or absence of follicle-stimulating hormone and bone morphogenetic protein 15 . Biol. Reprod. 87, 87.

SutTon-McDowall M. L., PuRdey M., BRown H. M., Abell A. D., MotTershead D. G., Cetica P. D., Dalvit G. C., Goldys E. M., Gilchrist R. B., Gardner D. K., Thompson J. G., 2015.
Redox and anti-oxidant state within cattle oocytes following in vitro maturation with bone morphogenetic protein 15 and follicle stimulating hormone. Mol. Reprod. Dev. 82, 281-294.

TACHIBANA M., SPARMAN M., SRITANAUdOMCHAI H., MA H., ClepPer L., WOODWARD J., LI Y., RAMSEY C., KOLOTUSHKINA O., MitaliPOV S., 2009. Mitochondrial gene replacement in primate offspring and embryonic stem cells. Nature 461, 367-372.

TaChibana M., AMato P., SPARMan M., WoOdWARD J., SANChis D. M., MA H., Gutierrez N. M., TiPPNER-Hedges R., KANG E., LEE H.-S., RAMSey C., Masterson K., BatTaglia D., LEe D., Wu D., JENSEN J., PATTON P. GOKHALE $S$., STOUFFER R., MitalipoV S., 2013. Towards germline gene therapy of inherited mitochondrial diseases. Nature 493, 627-631.

TACHIBANA M., SPARMAN M., SRITANAUDOMCHAI H., MA H., Clepper L., WOODWARD J., Li Y., RAMSEy C., Kolotushkina O., Mitalipov S., 2014. Corrigendum: Mitochondrial gene replacement in primate offspring and embryonic stem cells Nature 516, 276-276.

TakeO S., Sato D., Kimura K., Monji Y., KuwaYAMA T., KAWAHARA-MIKI R., IWATA H., 2014. Resveratrol improves the mitochondrial function and fertilization outcome of bovine oocytes. J. Reprod. Dev. 60, 92-99.

TAMURA H., TAKasaki A., Miwa I., TANiguchi K., Maekawa R., Asada H., Taketani T., MatsuoKA A., YAmagata Y., Shimamura K., MORIOKA H., Ishikawa H., Reiter R. J., Sugino N., 2008. Oxidative stress impairs oocyte quality and melatonin protects oocytes from free radical damage and improves fertilization rate. J. Pineal Res. 44, 280-287.

TARIN J. J., BRINES J., CANO A., 1998. Antioxidants may protect against infertility. Hum. Reprod. 13, 1415-1416.

Tarín J. J., Pérez-Albalá S., Cano A., 2002. Oral antioxidants counteract the negative effects of female aging on oocyte quantity and quality in the mouse. Mol. Reprod. Dev. 61, 385-397.

Tatone C., Emidio G., Di VitTi M., CARlo M., Di JR S. S., AlESSANDRO A. M. D., FAlONE S., AMICARELLI F., 2015. Sirtuin functions in female fertility : possible role in oxidative stress and aging. Oxid. Med. Cell. Longevity 2015, $1-11$.

VoGel G., 2014. Assisted reproduction. FDA considers trials of "three-parent embryos". Science 343, 827-828.

Wallace D., C., Chalkia D., 2013. Mitochondrial DNA genetics and the heteroplasmy conundrum in evolution and disease. Cold Spring Harb. Perspect. Biol. 5, doi: 10.1101/cshperspect.a021220.

WANG N., LUO L.-L., XU J.-J., XU M.-Y., ZHANG X.-M., ZHOU X.-L., LIU W.-J., FU Y.-C., 2014. Obesity accelerates ovarian follicle development and follicle loss in rats. Metabolism. 63, 94-103.

WANG Q., SUN Q.-Y., 2007. Evaluation of oocyte quality: morphological, cellular and molecular predictors. Reprod. Fertil. Dev. 19, 1-12.

WANG Q., RATCHFORD A., M., CHI M. M.-Y., Schoeller E., Frolova A., Schedl T., Moley K. H., 2009. Maternal diabetes causes mitochondrial dysfunction and meiotic defects in murine oocytes. Mol. Endocrinol. 23, 16031612.

Wang T., Sha H., Ji D., Zhang H. L., Chen D., CAO Y., ZHU J., 2014. Polar body genome transfer for preventing the transmission of 
inherited mitochondrial diseases. Cell 157, 1591-1604.

Weall B. M., Al-Samerria S., CONCEicaO J., Yovich J. L., AlmahBoBi G., 2015. A direct action for $\mathrm{GH}$ in improvement of oocyte quality in poor-responder patients. Reproduction 149, 147-154.

Wu L. L., Russell D. L., Wong S. L., Chen M., TSAI T.-S., ST JOHN J., C., NORMAN R. J., FEbBraio M. A., CARroll J., RoBKer R. L., 2015. Mitochondrial dysfunction in oocytes of obese mothers: transmission to offspring and reversal by pharmacological endoplasmic reticulum stress inhibitors Development 142, 681691.
YI X., MAEDA N., 2005. Endogenous production of lipoic acid is essential for mouse development. Mol. Cell. Biol. 25, 8387-8392.

ZEVIANI M., Di DonATO S., 2004. Mitochondrial disorders. Brain 127, 2153-2172.

Zhang L., HOU X., MA R., MOley K., Schedl T., WANG Q., 2014. Sirt2 functions in spindle organization and chromosome alignment in mouse oocyte meiosis. FASEB J. 28, 14351345.

Zhang X., Li L., Xu J., Wang N., LiU W., Lin X., FU Y., LuO L., 2013. Rapamycin preserves the follicle pool reserve and prolongs the ovarian lifespan of female rats via modulating mTOR activation and sirtuin expression. Gene 523, 82-87.

KOSMOS Vol. 67, 3, 495-507, 2018

ŁUKASZ GẠSIOR, ZBIGNIEW POLAŃSKI

Institute of Zoology and Biomedical Research, Jagiellonian University in Kraków, 9 Gronostajowa Str., Kraków 30-387,

E-mail: lukasz.gasior@doctoral.uj.edu.pl

STRATEGIES TO RESTORE AND MAINTAIN MITOCHONDRIAL QUALITY IN MAMMALIAN OOCYTES

Female germ cells comprise essentially immortal cell line which transmits the nuclear and mitochondrial genomes throughout generations. Heteroplasmy is defined as the presence of two types of mtDNA in the cell, the wild type mtDNA and the mutated mtDNA. It is considered that cells possess natural mechanisms preventing from accumulation of mtDNA mutations. However, this process is not always fully sufficient and its efficiency may be additionally impaired during aging. This results in a considerable proportion of mitochondrial abnormalities and diseases in the human population. Therefore, scientists are looking for methods that could improve the quality of mitochondria as well as delay the adverse effects of aging processes that negatively affect both the quality of the mitochondrial genome and the fertility in mammals.

Key words: fertility, heteroplasmy, mitochondria, mtDNA, oocyte 